\title{
Effects of Maternal Education, Psychosocial Stress, Nutritional Status at Pregnancy, and FamilyIncome, on Birthweight in Nganjuk, East Java
}

\author{
Dhewi Nurahmawati, ${ }^{1,2)}$, Harsono Salimo3), Yulia Lanti Retno Dewi4) \\ 1)Academy of Midwivery PGRI, Kediri, East Java \\ 2)Masters Program in Public Health, Sebelas Maret University \\ 3)Department of Pediatrics, Dr. Moewardi Hospital, Surakarta \\ 4)Department of Nutrition,Faculty of Medicine, Sebelas Maret University
}

\begin{abstract}
Background: Low birth weight (LBW) is one of the primary causes of infant mortality. It shares $27 \%$ of infant mortality rate (IMR). The Indonesian Demographic and Health Survey in 2007 reported that the IMR was 34 deaths per 1,000 live births. As much as $30.3 \%$ of this rate was accounted by LBW. As such LBW is an important global public health issue. Countries around the world have committed to overcome this problem. This study aimed to investigate the effects of maternal education, psychosocial stress, nutritional status at pregnancy, and family income, on birth weight.

Subjects and Method: This was an observational analytic study with case control design. The study was conducted in Ngetos community health center, Nganjuk, East Java, from May to June, 2017. A total sample of 120 were selected for this study by fixed disease sampling, comprising 40 infants with low birth weight and 80 infants with normal birth weight. The dependent variable was birth weight. The independent variables were maternal education, psychosocial stress, nutritional status at pregnancy (middle-upper arm circumference, MUAC), maternal anemia, and family income. MUAC was measured by MUAC measuring tape. Hemoglobin concentration was measured by Sahli meter. Psychosocial stress was measured by Holmes and Rahe stress scale. The other variables were measured by a set of questionnaire. Path analysis was used for data analysis.

Results: MUAC $\geq 23.5 \mathrm{~cm}(\mathrm{~b}=-0.80, \mathrm{SE}=0.57 ; \mathrm{p}=0.064)$, hemoglobin concentration $\geq 11 \mathrm{~g} / \mathrm{dL}(\mathrm{b}=$ -120.16, $\mathrm{SE}=45.14, \mathrm{p}=0.008)$, and low psychosocial stress $(\mathrm{b}=-0.8 \mathrm{o}, \mathrm{SE}=0.57, \mathrm{p}=0.164)$ directly and negatively affected low birth weight. Maternal education $\geq$ Senior High $\operatorname{School}(b=1.28, S E=$ $0.056, p=0.022)$, psychosocial stress $(b=-0.001, \mathrm{SE}<0.001, \mathrm{p}=0.097)$, and family income $(\mathrm{b}=$ $0.97, \mathrm{SE}=0.46, \mathrm{p}=0.036)$ positively affected MUAC. MUAC $\geq 23.5 \mathrm{~cm}$ positively affected hemoglobin concentration $\geq 11 \mathrm{~g} / \mathrm{dL}(\mathrm{b}=0.19, \mathrm{SE}=20.84, \mathrm{p}<0.001)$.
\end{abstract}

Conclusion: MUAC, hemoglobin concentration, and low psychosocial stress directly and negatively affect low birth weight.

Keywords: low birth weight, MUAC, maternal anemia, psychosocial stress, family income

\section{Correspondence:}

Dhewi Nurahmawati. Masters Program in Public Health, Sebelas Maret University, Jl. Ir. Sutami 36 A, Surakarta 57126, Central Java. Email: dhenoura@gmail.com. Mobile: +62813330787826.

\section{BACKGROUND}

The constantly towering maternal and infant death in Indonesia is still the main focus of health problem breakthrough. Infant Mortaity Rate in Indonesia is still categorized as high, among Assosiation East Asian Nation (ASEAN) countries, (Negi, et al,
2010). As developing countries Infant Mortality Rate (IMR) in Indonesia is also still high. Based on the Indonesian Demographic and Health Survey 2007 the IMR (SDKI) reported that the IMR was 34 deaths per 1000 live births and it declined in 2012 into 32 deaths per 1000 live births and majority of infant mortality occurs to 
neonates (Depkes RI, 2013). The result of Intercensal Population Survey (SUPAS) 2015 showed that the IMR was 22.23 per 1,00o live births, means it has achieved the target of MDG 2015 of 23 per 1,00o live births (Kemenkes RI, 2016).

Infant Mortality Rate (IMR) represents the level of public health problems associated with the causes of infant mortality, antenatal care rate, nutritional status of pregnant women, $\mathrm{MCH}$ and family program accomplishment level, as well as the condition of social economy and environment. High IMR indicates low health status of the region (Depkes RI, 2013). Causes that possibly influence infant's birth weight are maternal factor environmental factor, and fetal factor. Factors derived from maternal factor are maternal age which is too young ( $<20$ years) or too old ( $\geq 35$ years), too short pregnancy spacing ( $<1$ year), history of LBW, performing physical activities for several hours without resting, very poor, pregnancy weight gain or malnutrition, smoking mother or drugs or alcohol user mother, pregnant women with anemia, preeclampsia or hypertension, infection during pregnancy, multiple pregnancy, and infant with congenital defect (Depkes, 2008).

According to Simanjuntak NA (2009) in Rini (2012) maternal Hemoglobin (Hb) levels greatly influence the weight of infant to be born. Anemic mother does not only endanger mother's life but also interferes fetal growth and development as well endangers fetal life. Anemia in pregnant woman will add the risk for having LBW (Rini, 2012). A woman who insists to get pregnant with poor nutritional status is 2- 3 times at risk to deliver LBW infant and 1.5 times possibility for the infant to die compare to woman with good nutritional status (Soetjiningsih, 2013).

Anemia is the main health problem suffered by pregnant women in developing countries, such as Indonesia. The underlying factors that cause anemia gravidarum are low income, low knowledge, low education, and psychological stress as well as socio-cultural factor (Istiarti, 2000). Low educational level is one of the underlying factors of malnutrition. Low educational level will complicate people to obtain feasible job. It leads to the low income that generates the low consumption of good quality and quantity of food (Supariasa, 2016).

Based on Basic Health Research (Riskesdas) 2013, in Indonesia there were a total of $37.1 \%$ of pregnant women who suffered from anemia with almost similar proportion between urban area with $36.4 \%$ and rural area with 37.8\% (Kemenkes RI, 2014). The incidence rate of anemia in East Java province in 2009 was $4.88 \%$ and in the cities was $12.65 \%$.

The trend of LBW incidence in Nganjuk Regency was increasing the the past year that was in 2015 particularly in Ngetos and Sawahan sub-district. The highest LBW cases ever recorded in Nganjuk Regency was 56 cases, in addition in 2015 Ngetos and Sawahan Sub-district ranked the first with 61 cases (Dinkes Nganjuk, 2015).

The report of Basic Health research 2013 showed that LBW prevalence rate was increasing influenced by nutritional status of pregnant women and anemia gravidarum (Depkes RI, 2013). The study aimed to analyze the effect of educational level, family income, psychosocial stress, nutritional status, and anemia gravidarum on LBW incidences in Nganjuk Regency.

\section{SUBJECTS AND METHOD}

\section{Design of the Study}

The study was analytical observational study. The design of the study employed was case control. The study was conducted in the area of Ngetos Puskesmas of Ngetos 
Sub-district, Nganjuk Regency, East Java. It was conducted in May up to June 2017.

\section{Population and Sample}

The target population of the study was all mothers who had delivered LBW infants under the working area of Ngetos Puskesmas of Nganjuk Regency. The number of sample was 120 comprising mothers who had delivered infants and it was selected by using fixed disease sampling. The sample of the study consisted of 40 people of case group and 80 people of control group. The case group of the study included mothers who had delivered Low Birth Weight $(<2,500$ gram) infants, whereas the control group consisted of mothers who had delivered infants with Normal Birth Weight ( $\geq 2500$ gram).

Inclusion criteria of case sample among others were pregnant women with anemia gravidarum who had delivered infants with Low Birth Weight (<2500 gram), who had 0-12 months old infants and owned $\mathrm{MCH}$ book. Inclusion criteria of control sample were women who had delivered infants with normal birth weight $(\geq 2,500$ gram), who had infants of more than 12 months old. Meanwhile the exclusion criteria were women who had delivered infants with Normal Birth Weight ( $\geq 4$,ooo gram), who had infants of more than 12 months old and refused to join the study.

\section{Sampling Technique}

The sampling technique used in the study was fixed disease sampling which is a selection scheme based on the status of the disease being studied, whereas the subject's exposure status is varied in accordance with the disease status. There were a total of 120 subjects comprising 40 case subjects and 80 control subjects.

\section{Variables of the Study}

There were six variables in the study consisted of dependents, intermediate, and independent variables. The dependent variable was LBW. The independent variables consisted of educational level, family income, and psychosocial stress. The intermediate variables were nutritional status, and anemia gravidarum

\section{Operational Definition}

Operational definition of educational level was the last formal education level finished by mother of the infant; family income was income as the family's economy resource for a whole month; psychosocial was stress occurred for the last 12 months ignited by life events; nutritional status was nutriational status of a mother during pregnancy. Anemia gravidarum was HB concentration of a mother during pregnancy which was under normal limit.

Definition of low birth weight was body weight assessment by performing act of weighing which was measured in unit of gram and performed within the first hour after delivering the infant of the study subject and also recorded in $\mathrm{MCH}$ book.

\section{Instruments of the Study}

The collected data consisted of primary and secondary data. The primary data used included educational level, family income, maternal psychosocial stress, maternal nutritional status during pregnancy, hemoglobin concentration, and infant's birth weight.

\section{Data Analysis}

The study employed Amos 22 path analysis. Path analysis is an analysis technique which is employed to know the effect of an exogenous variable on endogenous variable either directly or indirectly (Murti, 2013). The degree of effect of exogenous variables toward endogenous variable could be observed from the value of path coefficient, the bigger the path coefficient was, the bigger also the effect given by the variables will be. 


\section{RESULT}

Table 1 showed the characteristics of the study subjects that most of the study subjects with a total of 75 study subjects (62.5\%) were in the reproductive age which was between 26-35 years old and there were 2 respondents (1.7\%) who were at highrisk pregnancy age. Most of the study subject infants with a total of 71 infants (59.2\%) were between 0-6 months old and the majority which were 75 infants $(54.2 \%)$ were male.

The univariate frequency distribution of variables of the study explained general description of each variable being studied comprising educational level, family income, maternal psychosocial stress during pregnancy, maternal nutritional status during pregnancy, anemia gravidarum, and birth weight of the infants. Table 2 showed that educational level of the study subjects was mostly categorized in low educational level (elementary school) with a total of 58 study subjects (48.3\%). The study subjects' family income were mostly below Regional Minimum Wage of Nganjuk Regency with 72 study subjects (60\%) and the rest that were 48 (40\%) study subjects were above Regional Minimum Wage.

Most of the study subjects with a total of 75 study subjects (62.5\%) endured psychosocial problem and stress. The nutritional status of most study subjects (MUAC) with a total of 108 study subjects (90\%) was excellent. HB concentration of 60 study subjects (50\%) was normal or they did not suffer from anemia gravidarum. In accor- dance with the aim of the study 80 study subjects (66.7\%) with normal birth weight belonged to control group and 40 study subjects (33.3\%) with low birth weight belonged to case group.

Table 3 was a bivariate analysis on the effect of independent variables on the incidence of LBW (dependent variable) in Ngetos village, Nganjuk Regency. Independent variables included maternal education, family income, psycholsocial stress, nutriational status, and anemia gravidarum.

Table 3 showed that high educational level $(\mathrm{r}=0.06, \mathrm{p}<0.529)$, high income $(\mathrm{r}=$ $0.04, \mathrm{p}=0.696)$, psychosocial stress $(\mathrm{r}=-$ 0.04, $\mathrm{p}=0.692)$, good nutritional status (MUAC) ( $\mathrm{r}=0.06, \mathrm{p}=0.523)$, anemia gravidarum (HB concentration) $(\mathrm{r}<0.01, \mathrm{p}=$ 1.00o) effected the low birth weight and statistically significant.

Figure 1 showed structural model after an estimation was conducted by using IBM SPSS AMOS 22, hence it obtained values as it was stated in the figure. Indicators that showed model fit of path analysis of path analysis as it was shown in Tabel 4 also showed the occurrence of fit measure that it obtained fit index CMIN result of 5.264 with the value of $\mathrm{p}=0.385>0.05$; $\mathrm{GFI}=0.986>0.90 ; \mathrm{NFI}=0.939>0.90$; $\mathrm{CFI}=0.996>0.90 ; \mathrm{RMSEA}=0.21<0.80$ it meant the empirical model met the determined criteria and it was in accordance with empirical data.

Table 1.Characteristics on general descriptions of study subjects

\begin{tabular}{llcc}
\hline \multicolumn{1}{c}{ Subjects' Characteristics } & \multicolumn{1}{c}{ Criteria } & Frequency & (\%) \\
\hline Mothers' age & $18-25$ years & 43 & 35.8 \\
& 26-35 years & 75 & 62.5 \\
\multirow{2}{*}{ Infants' age } & $\geq 35$ years & 2 & 1.7 \\
Infants' gender category & O - 6 months & 71 & 59.2 \\
& $7-12$ months & 49 & 40.8 \\
& Male & 75 & 54.2 \\
\hline
\end{tabular}


Table 2. Characteristics of Variables of the Study

\begin{tabular}{llcc}
\hline Subjects' Characteristics & \multicolumn{1}{c}{ Criteria } & Frequency & (\%) \\
\hline Maternal Education & Elementary & 58 & 48.3 \\
& Junior High School & 37 & 30.8 \\
& High School & 18 & 15 \\
& Associate's Degree & 6 & 5 \\
& Bachelor's Degree & 1 & 8 \\
Family Income & < Regional Minimum Wage & 72 & 60 \\
& $\geq$ Regional Minimum Wage & 48 & 40 \\
Psychosocial Stress & Not stressed & 45 & 37.5 \\
& Stressed & 75 & 62.5 \\
Nutritional Status (MUAC) & Good $(\geq 23.5 \mathrm{~cm})$ & 108 & 90 \\
& Insufficient $(<23.5 \mathrm{~cm})$ & 12 & 10 \\
Anemia Gravidarum & Anemic $(<11 \mathrm{~g} / \mathrm{dL})$ & 60 & 50 \\
\multirow{3}{*}{ Birth Weight } & Non Anemic $(\geq 11 \mathrm{~g} / \mathrm{dL})$ & 60 & 50 \\
& Normal & 80 & 66.7 \\
\hline
\end{tabular}

Table 3. Bivariate analysis on the effect of educational level, family income, psychosocial stress, nutritional status of pregnant women with anemia gravidarum toward low birth weight incidences in Nganjuk Regency.

\begin{tabular}{lcc}
\hline Independent Variables & $\mathbf{r}$ & $\mathbf{p}$ \\
\hline Educational Level & 0.06 & 0.529 \\
Family Income & 0.04 & 0.696 \\
Psychosocial stress & -0.04 & 0.692 \\
Nutritional Status (MUAC) & 0.06 & 0.523 \\
Anemia Gravidarum (HB concentration) & 0.00 & 1.000 \\
\hline
\end{tabular}

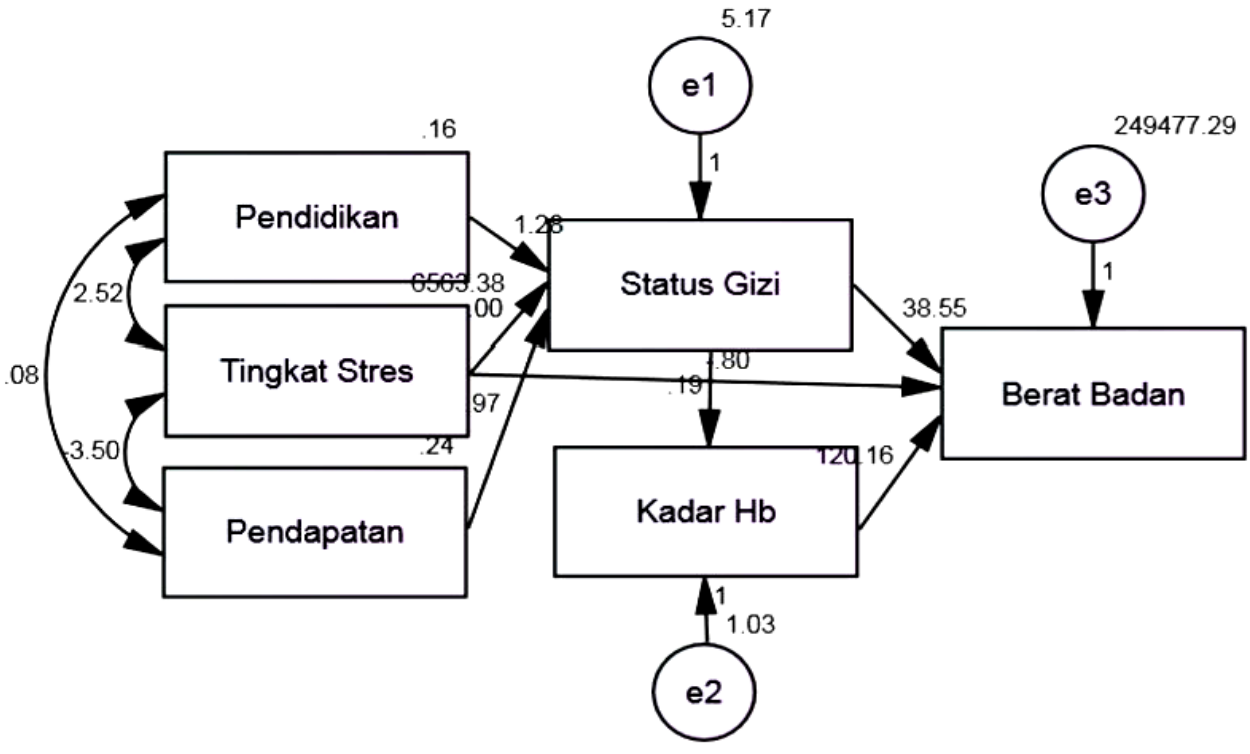

Figure 1. Structural Model of Path Analysis 
Journal of Maternal and Child Health (2017), 2(4): 327-337

https://doi.org/10.26911/thejmch.2017.02.04.04

Table 4. The result of path anlaysis on the effect of educational level, family income, psychosocial stress, nutritional status, anemia gravidarum toward LBW incidence in Nganjuk Regency

\begin{tabular}{lllcccc}
\hline Dependent Variables & & Variabel independen & $\mathbf{b}^{*}$ & SE & p & $\boldsymbol{\beta}^{* *}$ \\
\hline Direct Effect & & & & & & \\
Low Birth Weight & $\leftarrow$ & Low Psychosocial Stress & -0.80 & 0.57 & 0.164 & -0.12 \\
Low Birth Weight & $\leftarrow$ & MUAC $\geq 23.5 \mathrm{~cm}$ & -38.55 & 20.84 & 0.064 & -0.17 \\
Low Birth Weight & $\leftarrow$ & Hb Concentration $\geq 11 \mathrm{~g} / \mathrm{dL}$ & -120.16 & 45.14 & 0.008 & -0.25 \\
Indirect Effect & $\leftarrow$ & & & & & \\
LILA $\geq 23.5 \mathrm{~cm}$ & $\leftarrow$ & Educationn $\geq$ High School & 1.28 & 0.56 & 0.022 & 0.21 \\
LILA $\geq 23.5 \mathrm{~cm}$ & $\leftarrow$ & Low Psychosocial Stress & -0.04 & $<0.001$ & 0.097 & -0.14 \\
LILA $\geq 23.5 \mathrm{~cm}$ & $\leftarrow$ & High Income & 0.97 & 0.46 & 0.036 & 0.19 \\
KadarHb $\geq 11 \mathrm{~g} / \mathrm{dL}$ & $\leftarrow$ & MUAC $\geq 23.5 \mathrm{~cm}$ & 0.19 & 20.84 & $<0.001$ & 0.42 \\
Model Fit & & & & & & \\
CMIN & $=5.26$ & p $=0.385(\geq 0.05)$ & & & & \\
GFI & $=0.99$ & $\geq 0.90$ & & & & \\
NFI & $=0.94$ & $\geq 0.90$ & & & & \\
CFI & $=0.99$ & $\geq 0.90$ & & & & \\
RMSEA & $=0.21$ & $<0.08$ & & & & \\
\hline
\end{tabular}

From Table 4 it was observed that each increasing unit of psychosocial would reduce infant birth weight by -0.80 unit ( $\mathrm{b}=-$ $0.80, \mathrm{SE}=0.57, \mathrm{p}=0.164)$. Each increasing unit of MUAC $\geq 23.5 \mathrm{~cm}$ would lower infant birth weight by -38.55 unit $(b=-38.55$, SE $=20.84, \mathrm{p}=0.064)$. Each increasing unit of hemoglobin concentration $\geq 11 \mathrm{~g} / \mathrm{dL}$ would lower infant birth weight by -120.16 unit $(b=-120.16, S E=45.14, p=0.008)$.

Based on indirect effect of independent and dependent variables it can be observed that each increasing unit of educational level would increase educational status of pregnant women by 1.28 unit $(b=1.28, \mathrm{SE}=$ $0.056, p=0.022)$. Each increasing unit of psychosocial stress would lower nutritional status of pregnant women by -0.04 unit $(b=-0.04, S E=0.00, p=0.097)$. Each increasing unit of family income would increase nutritional status of pregnant women by 0.97 unit $(b=0.97, \mathrm{SE}=0.46, \mathrm{p}=0.036)$. Each increasing unit of nutritional status of pregnant women would increase hemoglo- bin concentration of pregnant women by 0.19 unit $(b=0.19, \mathrm{SE}=20.84, \mathrm{p}=<0.001)$.

\section{DISCUSSION}

\section{The Effect of Educational Level of Pregnant Women toward Low Birth Weight Incidence}

There was positive association between maternal educational level with LBW incidence and statistically significant. Education is a process of behavior change toward maturity and life completeness. Women with low educational level will have higher risk to deliver LBW infants. It is associated with self adjustment toward needs fulfillment for antenatal care.

Limited education may lead to limited access to healthcare and also there is a correlation with social economy status and affects maternal nutritional status that gives impact to the quality of maternal nutriational status during pregnancy. If the consumption pattern is appropriate, the nutrient intake will be sufficient, hence it is likely to avoid anemia. In contrast, low education is 
one of the underlying factors of malnutrition.

Ida (2000) in her study elaborated that a total of $67.5 \%$ mother with anemia have low educational level.

The study showed that there is indirect effect of maternal education toward LBW incidences with the occurrence of effect of maternal nutritional status and HB concentration factors during pregancy. Salmariantity (2012) showed the association between pregnant women's education with anemia incidence in a study by Ariadi (1995) that a total of $94.2 \%$ pregnant women with low suffer from anemia. In a society with low educational level, there are many beliefs and superstitions about food and it usually more difficult to change (Supariasa, 2011).

A study conducted by Silvestrin et al., (2013) stated that there is association between maternal edcutaional level with birth weight yet it is insignificant. Another study by Linsell et al (2015) conveyed that there is insignificant association between maternal educational level with low birth weight after considering parity.

\section{The effect of family income of preg- nant women toward LBW incidence}

The study showed that there was indirect association between family income and LBW incidence which is affected by factors of nutritional status and HB concentration or anemia gravidarum during pregnancy. There is the effect of income increase toward health and family condition improvement that establish interaction with nutriational status. Income and nutrition have advantageous correlation. Income is an important factor toward the quality and quantity of the food being consumed (Mohd S.et al, 2015), the higher income level is, the higher family consumption level will be (Curatman, 2010).

Family income plays role in the LBW incidences, it is supported by several other studies such as a study by Rahman, et al, (2016), low economy status is likely to suffer from anemia 2.6 times bigger compares to mother with moderate economy status. In a study conducted by Syafiq (2008) it showed that there is positive association between pregnant women's social economy status with the concentration of ferritin blood serum. Fitriyani (2002) in Salmariantity (2012) explained there are a total of $70 \%$ of pregnant women with anemia in low family economy level and there is significant association between the maternal family economy level with anemia gravidarum incidences.

Family income may affect the decline of LBW incidences, it is because families with high income ensure calorie and other nutrients intake for pregnant women hence the risk for delivering infants with birth weight $<2,500$ declines.

Therefore it can be concluded that there is indirect positive and significant effect of mother's family income toward LBW inidences with the existence of intervening variables namely maternal nutritional status and HB concentration during pregnancy therefore the result of the study that has been analyzed support the hypothesis of the study.

\section{The effect of psychosocial stress of pregnant women toward LBW incidence}

The study showed that there was the effect of maternal psychosocial toward LBW incidence. During pregnancy a mother should have peace of mind which comes from the support of her family environment, thus the mother can avoid from stress. Fetal growth, placenta growth, and transport of nutrients to fetus may get affected by the stress condition of the mother during pregnancy through bad effects that are endured by the mother (Soetjiningsih dan Ranuh, 2013; Supariasa et al., 2016). Psychosocial stress 
usually happens and in high level it may contribute to pregnancy products in the form of congenital defect and mental disorder (Woods et al., 2010; Supariasa et al., 2016).

Among several studies related to psychology stress and the supporting disease there is a study by Schneidermanet al., (2008) which explains that the trigger of chronic stress on pregnant women that is not followed by good stress management is related to low weight birth infants. According to Dozier et al, (2012) in premature birth the production of corticotrophin-releasing hormone (CRH) is increasing by placenta, the hormone functions to control pregnancy duration, the increasing concentration of it will speed up pregnancy duration, hence the fetus is at risk for premature birth and LBW.

Therefore it can be concluded that there is positive and approaching to significantly positive between maternal psychosocial stress, both directly and indirectly, toward LBW incidences affected by other factors namely nutritional status and HB concentration during pregnancy (anemia gravidarum).

\section{The effect of nutritional status of pregnant women toward LBW incidence}

The study showed that there was indirect affect of nutritional status of a mother during pregnancy, seen from MUAC during pregnancy, toward LBW incidences with the occurrence of another factor which was maternal HB concentration during pregnancy (anemia gravidarum) and it was significant. In which the indirect association can be explained as the following: first, the effect of positive association of maternal MUAC during pregnancy toward birth weight; second, the effect of positive association of maternal UAC during pregnancy with HB concentration or anemia gravida- rum toward birth weight which is LBW incidence. The study showed that there is association between maternal nutritional status during pregnancy with LBW and statistically significant and positive. The effect of positive association between maternal UAC during pregnancy with $\mathrm{HB}$ concentration or anemia gravidarum toward LBW is statistically significant and positive.

According to Barker, malnutrition on fetus which occurs during pregnancy will lead to fetal growth disorder. Pregnant women with malnutrition/ protein deficiency will pass on to the next generation. Abnormal fetal growth will lead to serious complication such as still birth, high rate of morbidity, and perinatal disorder that will be continued up to adulthood (Bourke and Barker, 1992; Wells JC, 2016).

The infant troubled condition in the first 100 days of life such as abnormal fetal growth, insufficient nutritional intake during pregnancy, will generate the occurrence of chronic diseases during adulthood (Pem D,2015). The chronic diseases among others are coronary heart disease, stroke, diabetes and hypertension. Infant birth weight is one of the important factors that determine the child's survival. The size of Upper Arm Circumference can be the determinant factor for birth weight and LBW incidence (Thomas R, et al).

Therefore it can be concluded that a quality of a child greatly depends on maternal nutritional status pre, during pregnancy. Maternal nutritional status can be observed from the size of UAC and maternal HB concentration during pregnancy or anemia gravidarum incidences. A pregnant woman with normal upper arm circumference size $(\geq 23.5 \mathrm{~cm})$ will not give birth to infant with LBW condition. Infant who is born with normal weight or non LBW will not endure growth problems later in the future. 


\section{The Effect of Nutritional Status of Pregnant Women toward Low Birth Weight Incidence}

The study showed that there was direct effect of anemia gravidarum during pregnancy toward LBW incidences and it is positive. The effect of direct association can be explained that anemia during pregnancy gives not quite so well effect to the mother, whether during pregnancy, child birth, as well as puerperium and the subsequent periods. The effects of anemia gravidarum during pregnancy among others are the occurrence of risks during antenatal period namely low birth weight (LBW), placenta praevia, eclampsia, premature rapture of the membrane; anemia during intranatal period can lead to inadequate power to strain, intranatal bleeding, shock; and during postnatal period it may cause subinvolution. Complications that may occur on neonates are premature birth, low APGAR score, and fetal distress (Mansjoer et al., 2008).

Placenta and fetal growth is interfered by decreased $\mathrm{HB}$ concentration as the result of the increasing volume of blood by $50 \%$ during pregnancy, increasing from 4 to $6 \mathrm{~L}$, plasma volume is slightly increasing that leads to the declining $\mathrm{HB}$ concentration and haematocrit value. The declining will be smaller on pregnant women who consume iron. (Smitht et al., 2010). Slow fetal growth, malnutrition fetus, premature birth and low birth weight by $38.85 \%$, are the causes of infant mortality. It indicates that $66.82 \%$ of perinatal deaths are affected by maternal condition during child birth.

A study by Simanjuntak (2009) in Labuan Batu Regency which studied the association of anemia on pregnant women with LBW incidences found that 86 (53\%) were anemic out of 162 cases and $36 \%$ gave birth to infants with LBW. The result of a study by Solomon (2007) showed that anemic pregnant women is four times at risk for delivering premature infants and 1.9 times at risk for delivering infants with low birth weight, compare to non anemic pregnant women.

\begin{tabular}{l}
\hline REFERENCE \\
\hline Adriani M, Wirjatmadi B (2013). Pengantar \\
Gizi Masyarakat. Jakarta: Kencana \\
Prenada Media Group. \\
Bourke CD, Berkley JA, Prendergast AJ \\
(2016). Immune Dysfunction as a \\
Cause and Consequence of Malnutria- \\
tion. Trends in Immunology, 37(6): \\
386-398. \\
Curatman A (2010). Teori Ekonomi Makro. \\
Yogyakarta: Swagati Press \\
Depkes RI (2008). Modul (Buku Acuan) \\
Manajeman Bayi Baru Lahir Rendah \\
(BBLR) untuk Bidan di Desa. Jakarta: \\
Departemen Kesehatan RI. \\
(2013). Laporan Hasil Riset Kese- \\
hatan Dasar (Riskesdas) Nasional \\
Tahun 2013. Jakarta: Departemen \\
Kesehatan RI. \\
(2008). Modul (Buku Acuan) Mana- \\
jeman Bayi Baru Lahir Rendah \\
(BBLR) untuk Bidan di Desa. Jakarta: \\
Departemen Kesehatan RI. \\
Dinatan
\end{tabular}

Dinkes Nganjuk (2015). Profil Kesehatan Kabupaten Nganjuk tahun 2015. Jakarta: Departemen Kesehatan RI.

Dozier AM, Nelson A, Brownell E (2012). The Relationship between Life Stress and Breastfeeding Outcomes among Low Income Mothers. Advances in Preventive Medicine. Hindawi $\mathrm{Pu}-$ blishing Corporation.

Kementrian Kesehatan Republik Indonesia (2014). Infodatin Pusat Data Dan Informasi Kementerian Kesehatan RI. Jakarta: Kementerian Kesehatan Republik Indonesia.

Kementrian Kesehatan Republik Indonesia (2016). Profil Kesehatan Indonesia Tahun 2015. Jakarta: Kementrian Kesehatan Republik Indonesia.

Linsell L, Malouf R, Morris J, Kurinczuk JJ, Marlow N (2015). Prognostic Factors for Poor Cognitive Development in Children Born Very Preterm or With 
Very Low Birth WeightA Systematic Review. JAMA Pediatr 169 (12):11621172.

Mansjoer A (2008), Kapita Selekta Kedokteran, Jakarta: Media Acsulapius.

Mohd SZ, Lin KG, Sariman S, Lee HS, Siew CY, Mohd BN, Mohamad M (2015). The relationship between household income and dietary intakes of 1-10 year old urban Malaysian. Nutrition Research and Practice, 9(3): 278-287.

Murti B (2013). Desain dan ukuran sampel untuk penelitian kuantitatif dan kualitatif di bidang kesehatan. Yogyakarta: Gajah Mada University Press.

Negi KS, Kandpal SD, Kukreti M (2010). Epidemiological Factors Affecting Low Birth Weight. Jk Science; 1 - 10.

PemD (2015). Factors Affecting Early Childhood Growth and Development Golden 1000 Days. Jornal of advanced practices in nursing 1 (1) 1-7.

Rahman MS, Howlader T, Masud MS, Rahman ML (2016). Association of Low-Birth Weight with Malnutrition in Children under Five Years in Bangladesh: Do Mother's Education, SocioEconomic Status, and Birth Interval Matter? Plos One, 11(6).

Rini SS, Trisna IW (2012). Faktor-Faktor Risiko Kejadian Berat Bayi Lahir Rendah di Wilayah Kerja Unit Pelayanan Terpadu Kesmas Gianyar II. Bali:Program Studi Pendidikan Dokter, Fakultas Kedokteran Universitas Udayana.

Salmariantity (2012). Faktor-faktor yang Berhubungan dengan Anemia pada Ibu Hamil di Wilayah Kerja Puskesmas Gajah Mada Tembilahan Kabupaten Indragiri Hilir Tahun 2012. Program Sarjana Kesehatan Masyara- kat Peminatan Kebidanan Komunitas, Fakultas Kesehatan Masyarakat; Universitas Indonesia. Depok.

Schneiderman N, Ironson G, Siegel SD (2008). Stres And Health: Psychological, Behavioral, and Biological Determinants. Annu Rev Clin Psychol. 1: 1-19.

Simanjuntak NA (2009). Hubungan Anemia Pada Ibu Hamil dengan Kejadian Bayi Berat Lahir Rendah (BBLR) di Badan Pengelola Rumah Sakit Umum (BPRSU) Rantauprapat Kabupaten Labuhan Batu Tahun 2008 [SKRIPSI]. Medan: Fakultas Kesehatan Masyarakat, Universitas Sumatera Utara.

Smith RJ,evid Chelnow, Chief, D evid Chelnow (2010). Managemet The Third Stage of Labor, Medscape reference, Available from http://emedicine. Medscape.com/article/275304overview.

Soetjiningsih, Ranuh G(2013). Tumbuh Kembang Anak. Jakarta: EGC.

Solomon NW (2007). Malnutrition and infection: an update. British Journal of Nutrition, 98: $\mathrm{S}_{5}-\mathrm{S} 10$.

Supariasa IDN, Bakri B, Fajar I (2016). Penilaian Status Gizi Edisi 2. Jakarta: EGC.

Syafiq (2008). Gizi dan Kesehatan Masyarakat. FKM, Universitas Indonesia. Depok: Departemen Gizi dan Kesehatan Masyarakat.

Woods SM, Melville JL, Guo Y, MSN4, Fan MY, Gavin A (2010). Psychosocial Stres during Pregnancy. Am J Obstet Gynecol, 202(1): 61.e1-61.e7. 